\title{
Effects of anthropogenic disturbances of tropical soft-bottom benthic communities
}

\author{
Patrick Frouin* \\ Laboratoire d'écologie marine, Université de la Réunion, BP 7151, 97715 Saint Denis Messag Cedex 9, France
}

\begin{abstract}
The benthic ecosystem of the lagoon surrounding Tahiti, the most populated island of French Polynesia, was investigated to assess the impacts of terrestrial runoff on these benthic communities. Five lagoonal zones based on population densities around the coast of Tahiti were identified, and within each zone a transect from the fringing reef to the barrier reef was sampled, a total of 18 stations. Only large macrofauna collected on a $2 \mathrm{~mm}$ sieve were considered in this study. Multivariate analysis using total biomass and environmental factors showed that the stations formed 3 main groups which were related to sediment characteristics, including percentage of silt, organic matter and phaeopigment levels. The distribution of the major feeding groups was related to the amounts of terrestrial inputs and distance from the shore. The stations on the barrier reef and those in zones adjacent to low population areas were not impacted by these terrestrial inputs. Deposit-feeding communities of capitellid polychaetes were dominant in the channel parts of the lagoon, which acted as decanting ponds. Chaetopterid polychaetes played an important rale in recycling sediments of terrigenous origin in the fringing ecosystem. The patterns of diversity, density and biomass of the benthos around the lagoon revealed that some areas were impacted by moderate terrigenous inputs. It appears that the intermediate disturbance hypothesis explains the functioning of the parts of the benthic lagoonal ecosystem which are subjected to human impact. The organic enrichment by terrestrial inputs contrasts with food limitation that appears to occur in the non-disturbed areas. Despite high organic loads, the benthic communities present at the harbour station were not depauperate, as bioturbation by burrowing alpheids and callianassids prevented anoxic conditions from developing.
\end{abstract}

KEY WORDS: Lagoon - Macrobenthic communities - Polychaetes · Deposit-feeders - Terrestrial inputs Tropical

\section{INTRODUCTION}

The effects of anthropogenic inputs on coastal marine ecosystems can be quantified by studying benthic communities subjected to varying levels of input (Pearson \& Rosenberg 1978). Soft-bottom macrobenthic communities have also been used to investigate levels of disturbance and human-mediated perturbations (Pearson \& Rosenberg 1978, Keough \& Quinn 1991, Ferraro \& Cole 1992, Engle et al. 1994). Such studies are generally undertaken as part of environmental impact studies before major development is undertaken. Polychaetes, a dominant component of such communities, especially capitellids, have often been

\footnotetext{
•E-mail: patrick.frouin@univ-reunion.fr
}

used to assess the effects of organic enrichment (e.g. Hily 1985, Plantecuny et al. 1993, Forbes et al. 1994, Heip 1995, Ellis \& Schneider 1997).

In the Pacific, numerous studies have been undertaken in atoll lagoons of the Tuamotu Archipelago as well as in Moorea, French Polynesia (see Hutchings et al. 1994). Even though most of French Polynesia's population lives on Tahiti, especially in or around Papeete, which is also the location of most of the industry within the territory, its lagoonal environment is poorly known (Frouin 1996). With increasing development in the coastal zone of the island, where the majority of the population lives, impacts are certainly occurring on lagoonal communities, but the existing data were inadequate to quantify them prior to this study. It is known that in the tropics, increased rates of sedimentation and eutrophication related to terrestrially derived or- 
Zone 2

HARBOUR ZONE
Zone 1

INDUSTRIAL ZONE

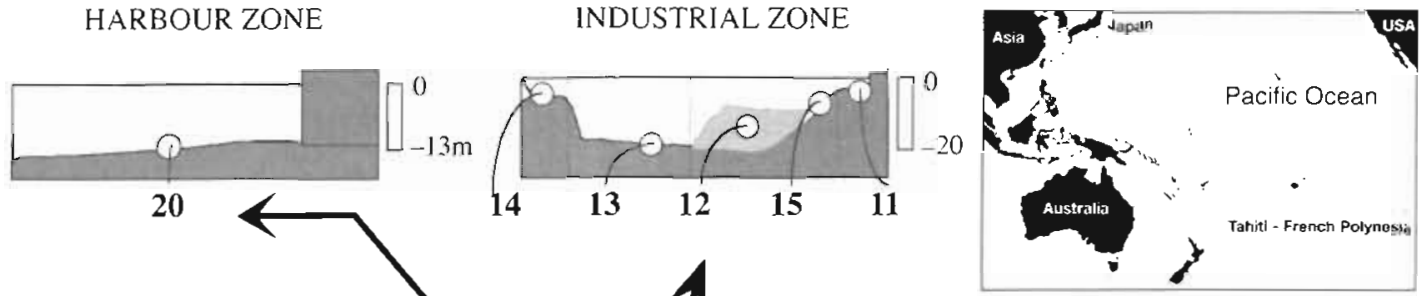

Zone 5

Zone 3

HOTEL ZONE
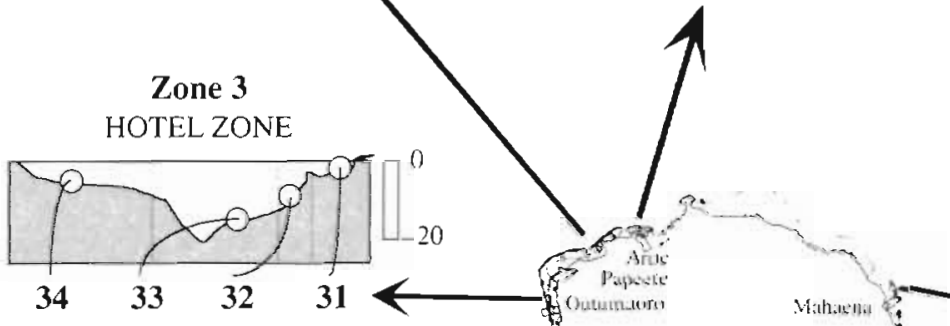
REFERENCE ZONE

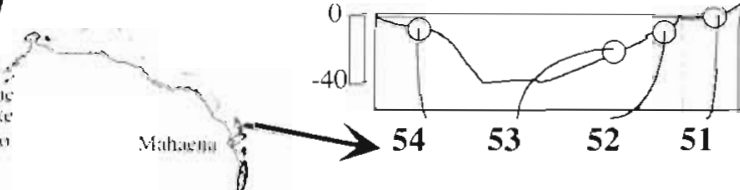

Zone 4 RESIDENTIAL ZONE

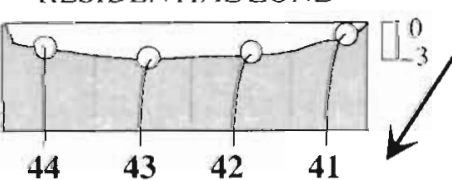

TAHITI
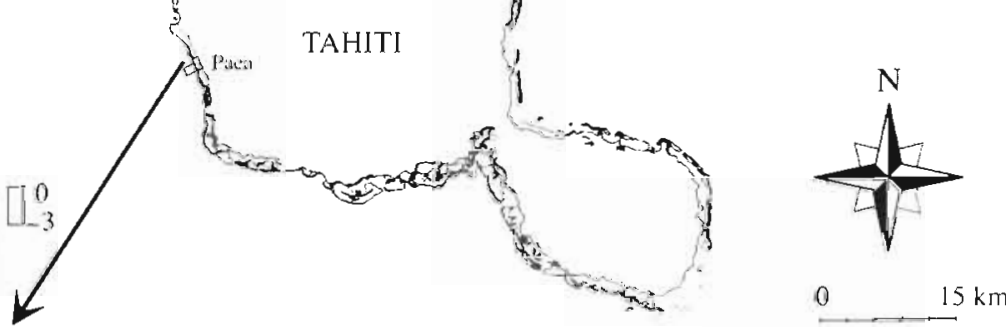

Fig. 1. Location of the 18 stations in the lagoon of Tahiti. The scale on the side of each zone shows approximate depth (m). The first digit of the station number relates to the zone, the second digit to reef morphology: 1 is for fringing reef (FR), 2 for fringing reef-channel transition (TR), 3 for channel $(\mathrm{CH})$ and 4 for inner flat of the barrier reef (BR). Example: 53 is channel station in Zone 5. Characteristics of zones and stations are shown in Table 1 and described in 'Material and methods'

ganic enrichment are the most significant sources of anthropogenic impacts on coral reefs (Hatcher et al. 1989, Grigg \& Dollar 1990).

The objective of this study was to investigate the soft-bottom macrobenthic communities of Tahiti lagoon and to assess the response of these communities to anthropogenic disturbances. It was assumed that these anthropogenic inputs were from the coastal zone and related to the densities of human populations around the island and associated industrial and tourist activities. As polychaetes dominated these benthic communities (Frouin \& Hutchings in press), both in terms of number of species and individuals, they were primarily used to investigate the effects of increased rates of sedimentation and organic enrichment from terrestrial inputs on these communities.

\section{MATERIAL AND METHODS}

Study area. Tahiti $\left(17^{\circ} \mathrm{S}, 149^{\circ} \mathrm{W}\right)$ is the main high basaltic island in French Polynesia, south-eastern Pacific Ocean, with a population of about 200000 inhabitants, most of whom live in and around Papeete, the capital. The majority of the wastewater is returned to the lagoon via rivers and creeks without any treatment (Hutchings et al. 1994). Stream flow is related to rainfall, which is about $2 \mathrm{~m}$ annually on the coast and more than $10 \mathrm{~m}$ in the mountains, with the highest rainfall occurring during the wet season (December to March). About 30 floods occur annually, $2 / 3$ of these occurring during the wet season (Lafforgue 1984).

Five zones (industrial, harbour, hotels, residential and reference) identified by the type of adjacent coastal development and population densities ran from the shore to the barrier reef. Four stations were sampled in each zone, fringing reef (FR), fringing reefchannel transition. (TR), channel $(\mathrm{CH})$ and in the inner flat of the barrier reef (BR). However, in Zone 2 (Papeete harbour) only 1 station of the $\mathrm{CH}$ type could be defined ( $\operatorname{Stn} 20$ ) and in Zone 1, 2 stations were sampled in the TR (Stns 12 and 15) because of the complex. reef morphology, so that a total of 18 stations were sampled (Fig. 1, Table 1). The location and physical characteristics of each station are given in Table 1 . together with a synopsis of the adjacent coastal development to each zone.

Sampling procedure. Macrofauna of soft-bottom sediments were sampled with large PVC corers $130 \mathrm{~cm}$ height, $11.5 \mathrm{~cm}$ wide) using SCUBA and sorted on a 
Table 1. General features of the stations ( $F R$, fringing reef; $T R$, fringing reef-channel transition; $\mathrm{CH}$, channel; $\mathrm{BR}$, inner flat of the barrier reef). Values in parentheses for organic load are standard error $(n=8$; except Stn 15 with $n=6$ and Stn 43 with $\mathrm{n}=7$ )

\begin{tabular}{|c|c|c|c|c|c|c|}
\hline Zone & $\begin{array}{l}\text { Zone type } \\
\text { (population) }\end{array}$ & Stn & $\begin{array}{l}\text { Station } \\
\text { type }\end{array}$ & $\begin{array}{l}\text { Depth } \\
\text { (m) }\end{array}$ & $\begin{array}{l}\text { Mean sediment } \\
\text { grain size (mm) }\end{array}$ & $\begin{array}{l}\text { Organic } \\
\text { load }(\%)\end{array}$ \\
\hline 1 & $\begin{array}{l}\text { Industrial Zone } \\
(20-40 \text { inhab. ha-1) }\end{array}$ & $\begin{array}{l}11 \\
15 \\
12 \\
13 \\
14\end{array}$ & $\begin{array}{l}\text { FR } \\
\text { TR } \\
\text { TR } \\
\text { CH } \\
\text { BR }\end{array}$ & $\begin{array}{c}<1 \\
6 \\
6 \\
18 \\
2.5\end{array}$ & $\begin{array}{l}0.464 \\
0.074 \\
0.043 \\
0.048 \\
0.682\end{array}$ & $\begin{array}{r}4.76(0.37) \\
13.40(0.70) \\
5.23(0.18) \\
13.31(0.32) \\
4.09(0.11)\end{array}$ \\
\hline 2 & $\begin{array}{l}\text { Harbour Zone } \\
(80-220 \text { inhab. ha-1) }\end{array}$ & 20 & $\mathrm{CH}$ & 13 & 0.032 & $12.65(0.26)$ \\
\hline 3 & $\begin{array}{l}\text { Hotel Zone } \\
\left(40-80 \text { inhab. } h a^{-1}\right)\end{array}$ & $\begin{array}{l}31 \\
32 \\
33 \\
34\end{array}$ & $\begin{array}{l}\mathrm{FR} \\
\mathrm{TR} \\
\mathrm{CH} \\
\mathrm{BR}\end{array}$ & $\begin{array}{c}<1 \\
9 \\
13 \\
2.5\end{array}$ & $\begin{array}{l}0.414 \\
0.081 \\
0.090 \\
0.860\end{array}$ & $\begin{array}{l}5.56(0.54) \\
4.44(0.19) \\
4.26(0.24) \\
3.62(0.06)\end{array}$ \\
\hline 4 & $\begin{array}{l}\text { Residential Zone } \\
\left(5-20 \text { inhab } \mathrm{ha}^{-1}\right)\end{array}$ & $\begin{array}{l}41 \\
42 \\
43 \\
44\end{array}$ & $\begin{array}{l}\mathrm{FR} \\
\mathrm{TR} \\
\mathrm{CH} \\
\mathrm{BR}\end{array}$ & $\begin{array}{l}<1 \\
2.5 \\
2.5 \\
3\end{array}$ & $\begin{array}{l}0.397 \\
0.630 \\
0.352 \\
0.771\end{array}$ & $\begin{array}{l}2.65(0.07) \\
3.76(0.13) \\
3.56(0.15) \\
4.01(0.14)\end{array}$ \\
\hline 5 & $\begin{array}{l}\text { Reference Zone } \\
\left(<5 \text { inhab. } \mathrm{ha}^{-1}\right)\end{array}$ & $\begin{array}{l}51 \\
52 \\
53 \\
54\end{array}$ & $\begin{array}{l}\mathrm{FR} \\
\mathrm{TR} \\
\mathrm{CH} \\
\mathrm{BR}\end{array}$ & $\begin{array}{c}<1 \\
9 \\
21 \\
2.5\end{array}$ & $\begin{array}{l}0.971 \\
0.287 \\
0.108 \\
0.500\end{array}$ & $\begin{array}{l}5.01(0.42) \\
8.75(0.70) \\
8.42(0.55) \\
4.27(0.21)\end{array}$ \\
\hline
\end{tabular}

$2 \mathrm{~mm}$ sieve. This mesh size was used to minimise sorting and identification time. Five $0.1 \mathrm{~m}^{2}$ samples were collected quarterly (April, July, October 1994 and January 1995). Animals were preserved in $5 \%$ formaldehyde, then stored in $70 \%$ alcohol. They were identified to the lowest possible taxonomic level (to species level for molluscs; as sp. 1, sp. 2, etc. for polychaetes; generally at higher levels for other taxonomic groups) and counted. As the majority of the animals had to be preserved for collections and subsequent taxonomic studies, biomass was assessed from individual ash-free dry weight (AFDW); for each species, individuals selected from replicated random samples were weighed (within $\left.10^{-4} \mathrm{~g}\right)$. AFDW refers to the difference between dry weight $\left(48 \mathrm{~h}, 60^{\circ} \mathrm{C}\right)$ and ash weight $\left(3 \mathrm{~h}, 550^{\circ} \mathrm{C}\right)$. Taxa were classified into feeding types according to Fauchald \& Jumars (1979) for polychaetes and Long \& Poiner (1994) for the other phyla.

The following sedimentary factors were measured: grain size, silt and clay fraction, organic load, chlorophyll and phaeopigment content, oxydo-reduction (redox) potential. The silt and clay fraction is referred to as silt in this paper. Sediment samples $\left(3 \times 0.001 \mathrm{~m}^{2}\right)$ were collected quarterly from May 1993 to January 1995. The upper centimetre of cores was analysed. Silt fraction was expressed as dry weight after wet sieving using a $63 \mu \mathrm{m}$ sieve. Chlorophyll pigments indicated densities of live microphytobenthos, and levels of phaeopigment indicated the amount of decaying vege- tal material present in the sediments. Chlorophyll and phaeopigment analyses were based on HolmHansen et al. (1965) and Lorenzen (1967). Redox potential measurements with an Eh platinum probe were made on the boat immediately after coring $(5.5 \mathrm{~cm}$ diameter core and repeated 3 times). Readings were performed on each core after $45 \mathrm{~s}$ stabilisation time. Total grain size data were determined from 1 core $(100 \mathrm{~g})$ collected at each station in November 1993. Sediment mean size was calculated using the formula

$$
T_{m}=(\varphi 16+\varphi 50+\varphi 84) / 3
$$

from Folk \& Ward (1957), conversion following Krumbein's formula (1936): $x_{\varphi}=-\log \left(x_{\mathrm{mm}}\right) / \log (2)$.

An estimate of the amount of terrigenous sediments carried out into the lagoon by coastal runoff was calculated from the basaltic content of lagoonal sediments. All stations in Zones 3, 4 and 5 and 2 stations in Zone 1 were sampled (total of 14 stations). Three sediment samples (each $0.001 \mathrm{~m}^{2}$ ) were collected in January 1995, rinsed and washed through a $63 \mu \mathrm{m}$ mesh sieve, dried and weighed. This sediment was then added to $5 \% \mathrm{HCl}$, and, after $12 \mathrm{~h}$, the sediment was rinsed and washed through a $63 \mu \mathrm{m}$ mesh sieve, dried and weighed. The fraction of the sediment which dissolved in the acid was regarded as the carbonate fraction and the remaining undissolved fraction as basalt and of terrigenous origins (Hily \& Frouin 1998). The island of Tahiti is composed mainly of basaltic material. The top centimetre of sediment was discarded, and sediment from 2 to $5 \mathrm{~cm}$ depth was analysed as 1 sample, in order to take into account the interannual temporal variation.

Data analysis. Two-way ANOVAs (station $\times$ date) followed by Newman-Keuls multiple range test $(\alpha=0.05)$ were performed on environmental variables (log transformed) and macrofauna density - $\log (x+1)$ - to assess significant seasonal effects (Frouin 1996). Data were transformed because of the presence of numerous null values.

Community structure was studied using ordinations performed with non-metric multi-dimensional scaling (MDS). Groups identified from group averaging cluster analysis were superimposed on the ordination plot for better segregation (Field et al. 1982, Clarke \& Green 1988). MDS analyses were performed with the 


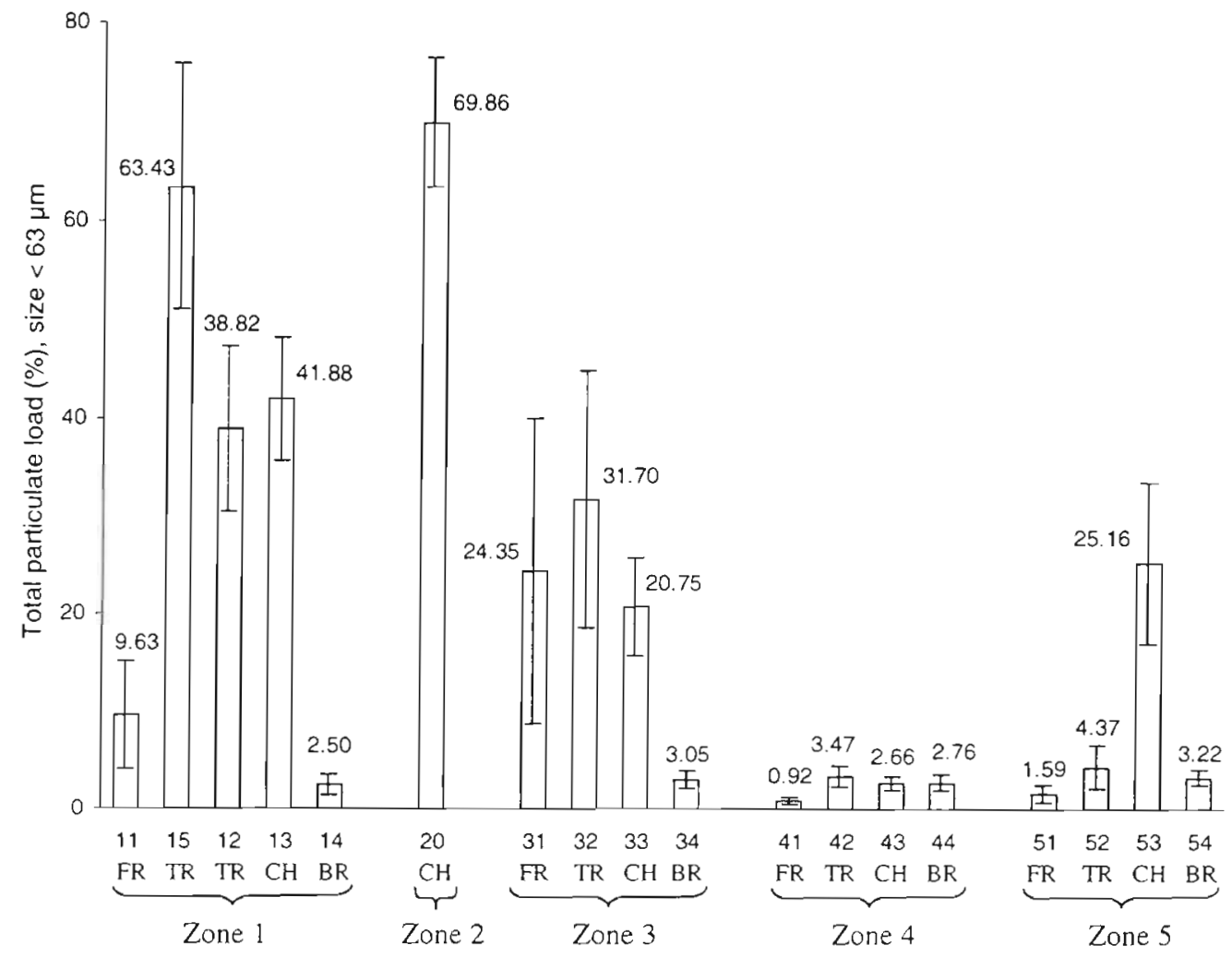

Fig. 2. Silt and clay load (particle size $<0.063 \mathrm{~mm}$ ) in sediments. Vertical bars are standard error $(n=8)$. Stations on $x$-axis. Highly significant differences in mean loads were highlighted with ANOVA test $(p<0.001)$. Newman-Keuls tests showed several homogeneous groups of stations for silt and clay content. From the lowest to the highest load these are Stns 41, 14, 43, 51, 44, 34, $54,42,52 / 11 / 33,31,53 / 32 / 12,13 / 15 / 20$

same configuration as in cluster analyses with respect to similarity index (Bray-Curtis) and fourth root transformation. Analyses of similarity (ANOSIM, Clarke \& Green 1988) were used to test differences between zones and between types of stations: the test statistic $\mathrm{R}$ indicates some degree of discrimination between sites. When $R$ significantly differs from 0 and tends towards 1 , intra-site similarity is higher than inter-site similarity.

Relationships between community biomass data and environmental data were investigated with a method used by Karakassis \& Eleftheriou (1997) and first described by Kruskal \& Wish (1978). The method consists of performing a multiple linear regression for each environmental variable, e.g. mean sediment size, redox potential, depth, phaeopigments, chlorophyll, silt and organic matter Each environmental variable was used as the dependent variable and the MDS co-ordinates as the independent variables. Regression weights were used to plot the direction of the environmental factor in the 2-dimensional MDS plot. The adjusted multiple correlation coefficients indicated the amount of variance explained by each variable.

\section{RESULTS}

\section{Seasonality}

Two-way ANOVAs on phaeopigments, total organic load and silt content revealed no significant seasonal effects $(\mathrm{p}>0.05)$, whereas chlorophyll load was higher in November 1994 ( $\mathrm{p}=0.03$ ) than at any other time. Macrofaunal density was significantly lower in October $1994(p<0.001)$ than at other times, but biomass showed no seasonal effect $(p=0.13)$. However, for all these variables, the effect of station was always more important than time $\left(F_{\text {spatial }}>F_{\text {temporal }}\right)$. As low temporal variability was exhibited, the results from the quarterly samples were summed and all subsequent analyses were carried out on the total mean value of macrofauna (Zmarzly et al. 1994)

\section{Sediments}

Mean grain size for each region of the lagoon was homogeneous, with coarse sand at BR stations, medium sand at FR stations and very fine sand to silt at $T R$ and 


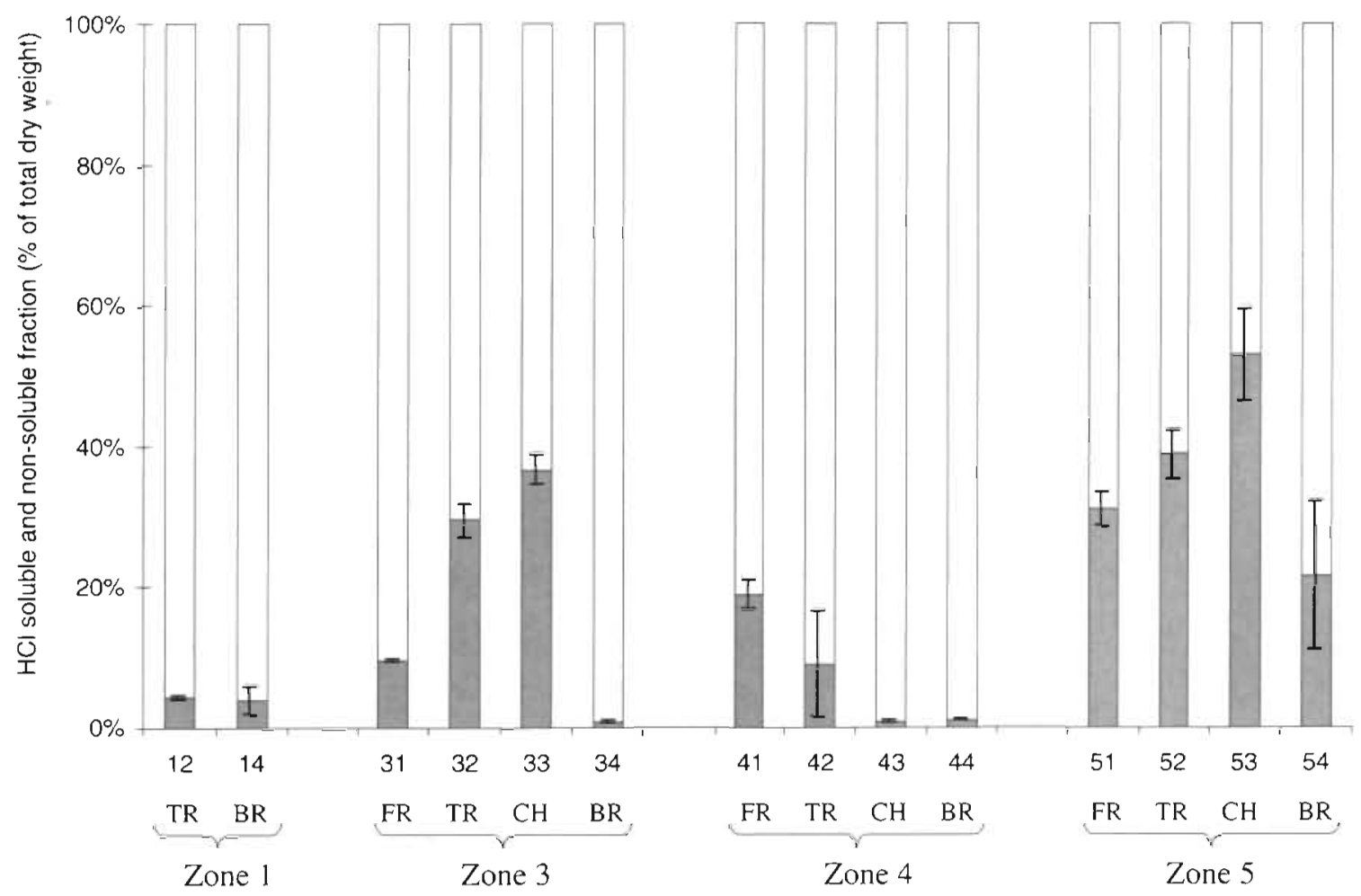

Fig. 3. Acid-soluble and non-soluble fraction in sub-surface sediments (2 to $5 \mathrm{~cm}$ depth, homogenised layer) as indicators of terrigenous inputs in the lagoon. Vertical bars are standard error $(n=3)$. Stations on $x$-axis

$\mathrm{CH}$ stations (Table 1). The silt fraction varied significantly between stations (ANOVA, $\mathrm{p}<0.001$ ), with 7 groups highlighted with the Newman-Keuls multiple range test (Fig. 2). The highest loads were recorded in the harbour (Stn 20 ) with $69.9 \%$ and $\operatorname{Stn} 15$ with $63.3 \%$, and the lowest loads at stations in the Residential and Reference Zones (except Stn 53) and at all BR stations (Fig. 2). All these stations with sediments containing less than $4.5 \%$ silt formed a group using the Newman-Keuls test.

The percentage of non-soluble material present in the sediment after washing in acid was used as an indicator of terrigenous inputs of basaltic origin (Fig. 3). The Residential Zone (Zone 4) showed that the percentage of terrestrially derived sediments declined from the fringing reef to the outer barrier, i.e. with increasing distance from shore. Zones 3 and 5 showed a reverse pattern with the percentage of terrestrially derived sediment increasing from the coast to the barrier reef, except for the inner barrier reef flat stations (Stns 34 and 54). Stations in the Industrial Zone (Stns 12 and 14), where runoff was limited, had low levels.

Considering total organic load of sediment, a KruskalWallis test $(p<0.05)$ revealed 3 groups of stations (Fig. 4). Highest organic loads were present at the TR and $\mathrm{CH}$ stations in the Industrial and Harbour Zones
(Stns 13, 15, 20 respectively), with up to $13.46 \pm 0.83 \%$. All other stations had much lower levels $(4.3 \pm 0.1 \%$ $\mathrm{n}=13)$, except Stns 52 and 53, both in the Reference Zone, which had intermediate levels (mean $8.6 \%$ ).

Chlorophyll and phaeopigments showed heterogeneous loads (ANOVA, $\mathrm{p}<0.001$ ), and no informative groupings were formed using the Newman-Keuls test. The mean value for all stations was $1.92 \pm 0.14 \mu \mathrm{g} \mathrm{g}^{-1}$ ( $\mathrm{n}=18$ ) for chlorophyll and $2.68 \pm 0.34 \mu \mathrm{g} \mathrm{g} \mathrm{g}^{-1}$ for phaeopigments. The lowest chlorophyll/phaeopigment ratios were recorded at $\mathrm{CH}$ stations, except for Stn 43 in the Residential Zone where the lagoon is shallow $(2.5 \mathrm{~m})$ and the sediment is white sand (Fig. 5). Stns 33 and 53, which were covered respectively with algae Halimeda spp. and seagrass Halophila decipiens, were not the stations with the maximum chlorophyll load in sediments. The harbour station (Stn 20) showed the highest phaeopigment load, and the lowest chlorophyil content.

Sediment cores collected for redox potential measurements did not show clear discontinuity in sediment colour. Only the harbour (Stn 20) showed a significant difference in depth for +100 and $+200 \mathrm{mV}$ potentials (ANOVA, $\mathrm{p}<0.001$ ), with the redox potential higher than $+100 \mathrm{mV}$ to depths of $20 \mathrm{~cm}$. 


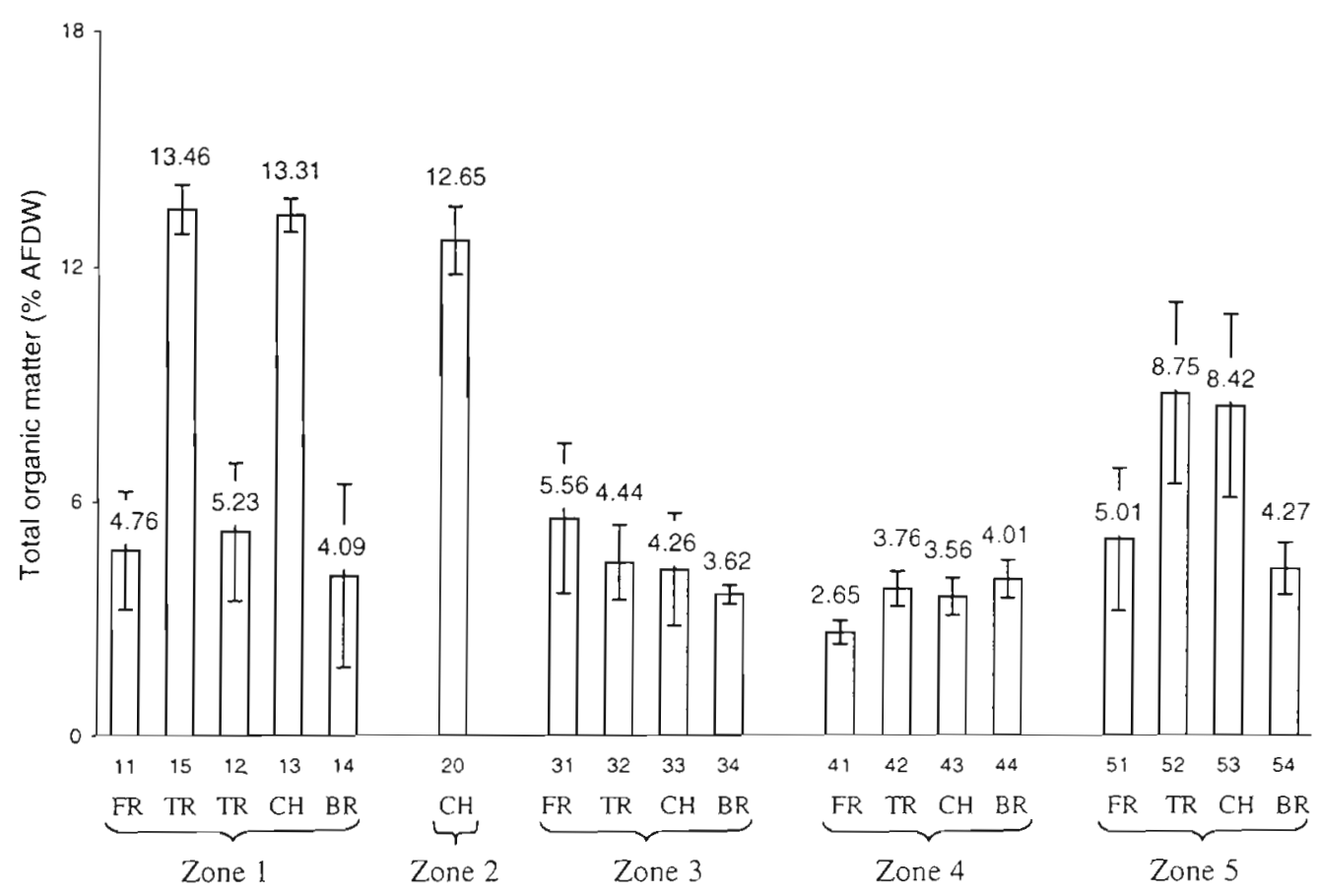

Fig. 4. Total organic content (\%) in sediments. Stations on $x$-axis. Three homogeneous groups of stations (Kruskal-Wallis, $\mathrm{p}<0.05$ ) present. Stns 13,15 and 20 for the highest organic load; Stns 52 and 53 for intermediate values; all remaining stations for low organic content. ADFW: ash-free dry weight

\section{Macrofauna biomass and taxonomic structure}

A total of 315 taxa were collected during the study, of which 100 were polychaetes. The mean macrofauna biomass was $1.54 \mathrm{~g} \mathrm{~m}^{-2} \pm 0.29(\mathrm{n}=18)$, and the mean density was $222 \pm 57$ ind. $m^{-2}(n=18)$. SAB (for species richness, abundance and biomass) curves showed that highest values occurred in the Hotel Zone (Zone 3) (Fig. 6), a zone with intermediate levels of terrigenous input (Fig. 3).

MDS ordination based on annual biomass showed 3 groups of stations and 3 isolated stations (Fig. 7). Group I included TR and CH stations from the Industrial Zone (Strns 15 and 13) and the harbour station (Stn 20), and was characterised by a dominance of

Table 2. Contribution of the main taxonomic groups to the total biomass. Each group of homogeneous stations was defined from the data analysis. Values are expressed as percent of the total biomass (AFDW). Group I: Stns 13, 15, 20; Group II: Stns 11, 12, 31-33, 53; Group III: Stns 14, 34, 42-44, 54

\begin{tabular}{lrrrrrr|}
\hline Taxon & Group I & Group II & Group III & Stn 41 & Stn 51 & Stn 52 \\
\hline Polychaeta & 50.8 & 27.6 & 10.2 & 58.4 & 13.3 & 3.9 \\
Gastropoda & 6.5 & 28.3 & 39.4 & 14.2 & 20.8 & 47.4 \\
Bivalvia & 8.0 & 22.0 & 29.5 & 4.3 & 5.3 & 37.5 \\
Decapoda & 18.9 & 13.3 & 7.0 & 7.1 & 57.0 & 8.7 \\
Sipuncula & 9.9 & 5.7 & 8.3 & 0.0 & 0.0 & 0.3 \\
Others & 6.0 & 3.1 & 5.6 & 16.0 & 3.6 & 2.2 \\
\hline
\end{tabular}

polychaetes (Table 2). The dominant species were the capitellid Dasybranchus sp. 1 (28.1 to $72.3 \%$ of the total biomass), and callianassid and alpheid decapods (5.3 to $24.2 \%)$.

Group III included all BR stations and stations from the Residential Zone, except Stn $41_{i}$ it was dominated by bivalves and gastropods $179.0 \%$ of the total biomass), including the bivalves Tellina spp. and Terebra spp. and the gastropods Conus spp. and Rhinoclavis diadema. Polychaetes accounted for only $10.2 \%$ of total biomass.

Group II showed an intermediate pattern, with Stns 11 and 12 (FR and TR for Industrial Zone), 31 to 33 (Hotel Zone except BR station) and 53 (Reference $\mathrm{CH}$ station). Polychaetes and gastropods dominated the biomass (Table 2), with bivalves also well represented $(22.0 \%$ of the total biomass).

Stns 41, 51 and 52 were not grouped and showed unique macrofaunal assemblages. Stn 41 was dominated by chaetopterid polychaetes Spiochaetopterus sp. 1 and Phyllochaetopterus sp. 1, Stn 51 by the decapod Hippa cf. pacifica, and Stn 52 by molluscs $(84.9 \%)$, especially Venus toreuma, Tellina rhomboides, Nassarius rehder, Terebra affinis and Nassarius spp. (Table 3). 


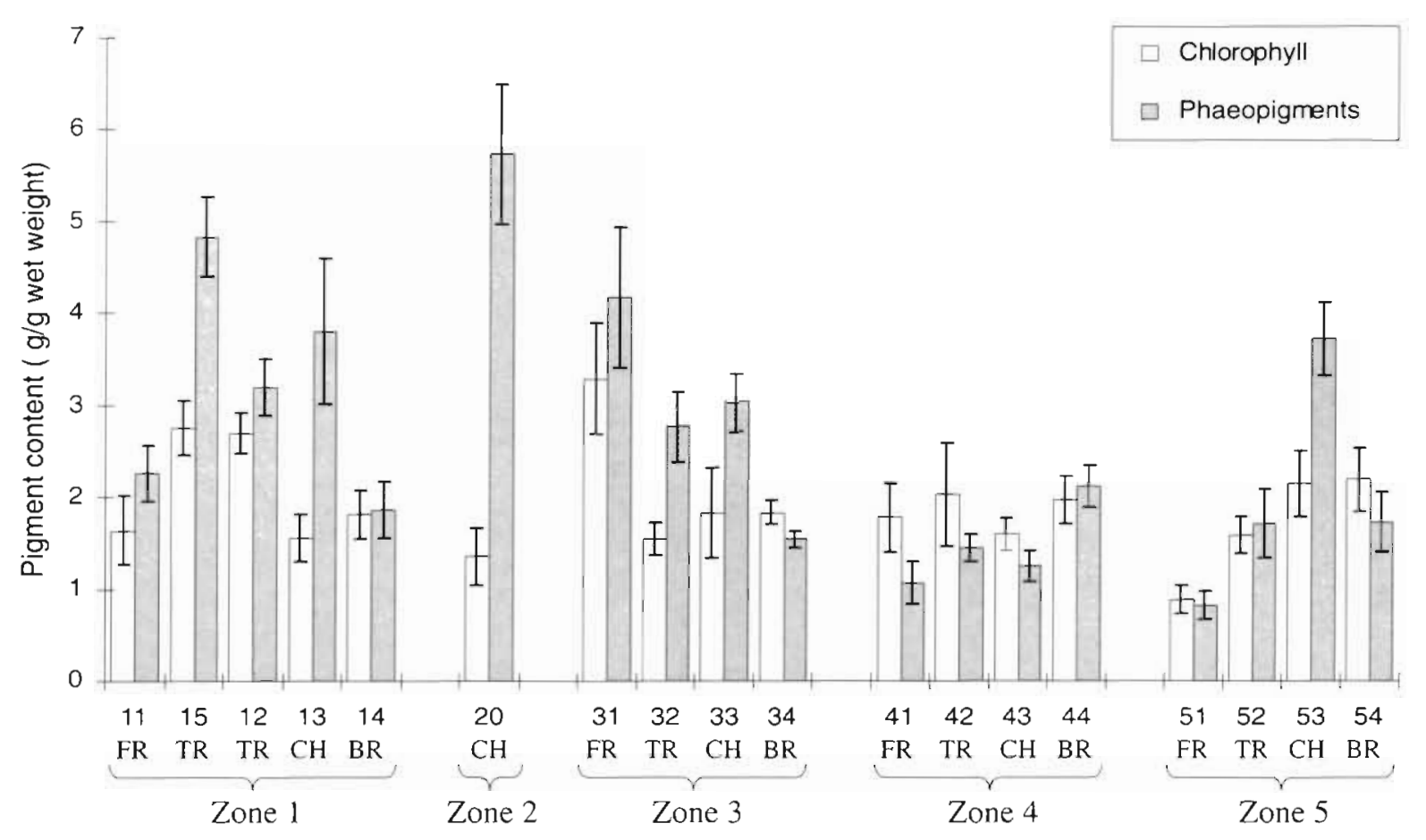

Fig. 5. Pigment load in sediments. Vertical bars represent standard error $(n=8)$. Stations on $x$-axis

Differences between zones and between types of stations were highlighted by ANOSIM tests on the total density of macrofauna present. Variability between zones was higher than variability between types of stations: respectively $\mathrm{R}=0.287, \mathrm{p}=0.008$ and $\mathrm{R}=0.132, \mathrm{p}=$ 0.086 . The same trend was observed for biomass: $\mathrm{R}=$ $0.254, p=0.014$ between zones and $R=0.201, p=0.024$ between stations. The highest dissimilarity was found between Zone 1 and Zone 4, indicating that the zones identified were more important in determining benthic community patterns than the type of station sampled across the lagoon.

\section{Trophic structure}

MDS ordination highlighted the trophic structure for the total macrofauna (Fig. 8A). The low spatial variability of feeding types revealed few distinct groups of stations ( 87 to $89 \%$ similarity level). The first group (Group A1) included the 3 stations from the Harbour and Industrial Zones, also defined as Group I in Fig. 7. In this group, the dominant trophic type was deposit-feeding. The non-selective deposit-feeder Dasybranchus sp. 1 dominated the group, particularly at Stns 15 and 20, which were closest on the MDS plot with a similarity of about $92 \%$ (Fig. 8A). The second group (Group A2) included the rest of the stations, except Stns 51 to 53 from the Reference Zone (Zone 5). Within that group carni- vores were dominant, although suspension-feeders characterised FR stations and selective deposit-feeders were present at Stns 14, 42 and 43. Stns 51, 52 and 53 in the MDS plot indicated distinctive trophic structure, all consisting of a range of feeding types. Stn 51 included $73.4 \%$ carnivores, $19.6 \%$ selective deposit-feeders, $4.1 \%$ herbivores and $2.7 \%$ suspension-feeders. Stn 52 included $53.5 \%$ carnivores, $26.7 \%$ selective depositfeeders and $17.6 \%$ suspension-feeders. Stn 53 included $38.6 \%$ selective deposit-feeders, carnivores and suspension-feeders being represented by 26.9 and $31.3 \%$ respectively, and herbivores and non-selective depositfeeders representing less than $2.5 \%$ of total biomass.

Using biomass of polychaete trophic groups, the MDS plot (Fig. 8B) revealed a greater number of cohesive groups of stations. The FR stations (Stns 11, 31, 41 and 51) showed the highest variability and were dominated by suspension-feeding chaetopterid polychaetes. The strongest similarity was between Stns 11 and 31 in the Industrial and Hotel Zones (Group B1). However Stn 51 was dominated by carnivores (including Glycera spp., Pisione sp. 1, amphinomids, arabellids). Stn 51 resembled Stn 52 (Group B4) in also having non-selective deposit-feeding species (dominated by capitellids and cirratulids). The $\mathrm{CH}$ stations (Stns 13, 20 and 33) and 1 TR station (Stn 15), formed a distinct group (Group B2) dominated by non-selective deposit-feeders especially capitellid species Dasybranchus sp. 1. The largest group of stations (B3) included 
Table 3. Distribution of taxa at 18 stations, according to biomass ranking. Only taxa accounting for $2 \%$ of total biomass or more are presented (SF, suspension feeders; CAR, carnivores; SDF, selective deposit-feeders; NSDF, non-selective deposit-feeders; HER, herbivores; - indeterminate)

\begin{tabular}{|c|c|c|c|c|c|c|c|}
\hline Taxon & $\begin{array}{c}\text { Total } \\
\text { biomass }(\%)\end{array}$ & $\begin{array}{c}\text { Cum. } \\
(\%)\end{array}$ & $\begin{array}{c}\text { Trophic } \\
\text { type }\end{array}$ & Taxon & $\begin{array}{l}\text { Total } \\
\text { iomass }(\%)\end{array}$ & $\begin{array}{c}\text { Cum. } \\
(\%)\end{array}$ & $\begin{array}{c}\text { Trophic } \\
\text { type }\end{array}$ \\
\hline Stn 11 & & & & Phascolosoma sp. 5 & 2.9 & 81.1 & SDF \\
\hline Phyllochaetopterus sp. 1 & 37.3 & 37.3 & $\mathrm{SF}$ & Glycera cf lancadivae & 2.4 & 83.5 & CAR \\
\hline Conus pulicarius & 8.4 & 45.7 & CAR & Alpheus sp. 1 & 2.2 & 85.7 & SDF \\
\hline Atys parallela & 5.6 & 51.3 & CAR & & & & \\
\hline Paraspidosiphon sp. 1 & 5.6 & 56.8 & $\mathrm{SDF}$ & Stn 31 & & & \\
\hline Conus eburneus & 4.5 & 61.3 & CAR & Mesochaetopterus sp. 2 & 32.6 & 32.6 & $\mathrm{SF}$ \\
\hline Dasybranchus sp. 1 & 3.8 & 65.1 & NSDF & Diopatra sp. 1 & 8.5 & 41.2 & CAR \\
\hline Phascolosoma sp. 5 & 3.6 & 68.7 & SDF & Dasybranchus sp. 1 & 7.7 & 48.8 & NDSF \\
\hline \multirow{2}{*}{ Arcopagia robusta } & 2.6 & 71.3 & SDF & Conus coronatus & 6.9 & 55.7 & CAR \\
\hline & & & & Thalamita sp. 1 & 4.2 & 59.9 & CAR \\
\hline Stn 12 & & & & Actinians & 4.0 & 64.0 & SF \\
\hline Conus eburneus & 27.1 & 27.1 & CAR & Phyllochaetopterus sp. 1 & 3.5 & 67.4 & SF \\
\hline Venus toreuma & 11.1 & 38.1 & $\mathrm{SF}$ & Macrophthalmus sp. 1 & 3.0 & 70.4 & SDF \\
\hline Corculum fragum & 4.4 & 42.6 & $\mathrm{SF}$ & Phyllochaetopterus sp. 2 & 3.0 & 73.4 & $\mathrm{SF}$ \\
\hline Phascolosoma sp. 5 & 3.8 & 46.3 & SDF & & & & \\
\hline Nassarius tabescens & 3.7 & 50.1 & CAR & $\operatorname{Stn} 32$ & & & \\
\hline Clavus pusilla & 3.5 & 53.6 & CAR & Conus eburneus & 11.0 & 11.0 & CAR \\
\hline Arcopagia robusta & 3.0 & 56.6 & $\mathrm{SDF}$ & Dasybranchus sp. 1 & 10.8 & 21.8 & NSDF \\
\hline Strombus gibberulus & 2.8 & 59.5 & SDF & Tellina tithonia & 6.9 & 28.7 & $\mathrm{SDF}$ \\
\hline Dasybranchus sp. 1 & 2.5 & 62.0 & NSDF & Cancilla filanis & 6.2 & 34.9 & CAR \\
\hline Terebra undulata & 2.5 & 64.4 & CAR & Thalamita sp. 3 & 4.9 & 39.8 & CAR \\
\hline Cancilla filaris & 2.3 & 66.7 & CAR & Venus toreuma & 4.4 & 44.2 & $\mathrm{SF}$ \\
\hline \multirow{2}{*}{ Glycera cf. lancadivae } & 2.2 & 68.9 & CAR & Arcopagia robusta & 4.2 & 48.4 & SDF \\
\hline & & & & Macrophthalmus sp. 1 & 3.7 & 52.1 & SDF \\
\hline Stn 13 & & & & Anodontia edentula & 3.2 & 55.3 & SDF \\
\hline Dasybranchus sp. 1 & 28.1 & 28.1 & NSDF & Callianassa sp. 3 & 3.1 & 58.4 & SDF \\
\hline Paraspidosiphon sp. 1 & 20.1 & 48.2 & SDF & Glycera cf. lancadivae & 3.0 & 61.5 & CAR \\
\hline Anodontia edentula & 8.0 & 56.2 & SDF & Actinians & 3.0 & 64.5 & $\mathrm{SF}$ \\
\hline Venus toreuma & 4.9 & 61.2 & SF & Paraspidosiphon sp. 2 & 2.7 & 67.2 & $\mathrm{SDF}$ \\
\hline Syndesmia seurati & 3.6 & 64.7 & $\mathrm{SDF}$ & Strombus mutabilis & 2.3 & 69.5 & SDF \\
\hline Terebra undulata & 2.5 & 67.2 & CAR & Callianassa indet. & 2.1 & 71.5 & $\mathrm{SDF}$ \\
\hline \multirow[t]{2}{*}{ Glycera cf. lancadivae } & 2.5 & 69.7 & CAR & & & & \\
\hline & & & & Stn 33 & & & \\
\hline Stn 14 & & & & Dasybranchus sp. 1 & 19.6 & 19.6 & NSDF \\
\hline Rhinoclavis diadema & 17.8 & 17.8 & $\mathrm{SDF}$ & Cerithium rostratum & 9.7 & 29.3 & SDF \\
\hline Phascolosoma sp. 3 & 16.3 & 34.1 & SDF & Thalamita sp. 1 & 7.2 & 36.5 & CAR \\
\hline Phascolosoma sp. 8 & 16.1 & 50.3 & $\mathrm{SDF}$ & Glycera cf. Lancadivae & 4.3 & 40.8 & CAR \\
\hline Conus tessulatus & 7.0 & 57.3 & CAR & Anodontia edentula & 3.7 & 44.5 & SDF \\
\hline Terebra affinis & 5.2 & 62.5 & CAR & Atys parallela & 3.4 & 47.9 & CAR \\
\hline Conus vitulinus & 3.5 & 66.1 & CAR & Portunus of. longispinosus & 3.2 & 51.1 & CAR \\
\hline Imbricaria olivaeformis & 3.1 & 69.2 & CAR & Natica gualteriana & 2.3 & 53.4 & CAR \\
\hline Eurythoe sp. 1 & 2.3 & 71.5 & CAR & Strombus mutabilis & 2.3 & 55.6 & SDF \\
\hline Rhinoclavis sinensis & 2.1 & 73.6 & SDF & Thalamita sp. 3 & 2.0 & 57.7 & CAR \\
\hline Stn 15 & & & & Stn 34 & & & \\
\hline Dasybranchus sp. 1 & 36.2 & 36.2 & NSDF & Terebra affinis & 10.2 & 10.2 & CAR \\
\hline Brachyura indet. & 8.4 & 44.5 & CAR & Tellina rhomboides & 9.5 & 19.7 & SDF \\
\hline Callianassa sp. 1 & 6.7 & 51.3 & SDF & Chiridota sp. 1 & 6.3 & 26.1 & NSDF \\
\hline Alpheus sp. 1 & 6.4 & 57.7 & $\mathrm{SDF}$ & Conus eburneus & 6.2 & 32.3 & CAR \\
\hline Blenniidae indet. & 6.3 & 64.0 & CAR & Eurythoe sp. 1 & 6.0 & 38.2 & CAR \\
\hline Callianassa sp. 2 & 5.7 & 69.7 & $\mathrm{SDF}$ & Spatangidae indet. & 5.9 & 44.1 & NSDF \\
\hline Nassarius tabescens & 3.2 & 72.8 & CAR & Nassarius graniferus & 4.6 & 48.7 & CAR \\
\hline Terebra longiscata & 2.7 & 75.5 & CAR & Tellina oahuana & 3.9 & 52.6 & SDF \\
\hline Callianassa indet. & 2.4 & 78.0 & $\mathrm{SDF}$ & Vexillum cadaverosum & 3.9 & 56.5 & CAR \\
\hline Glycera cf. lancadivae & 2.3 & 80.3 & CAR & Aspidosiphon sp. 1 & 3.9 & 60.4 & SDF \\
\hline \multirow[t]{2}{*}{ Paraspidosiphon sp. 1} & 2.1 & 82.4 & SDF & Glycera cf. lancadivae & 3.2 & 63.6 & CAR \\
\hline & & & & Callianassa sp. 1 & 2.9 & 66.5 & SDF \\
\hline Stn 20 & & & & Cerithium salebrosum & 2.5 & 69.1 & SDF \\
\hline Dasybranchus sp. 1 & 72.3 & 72.3 & NSDF & Phyllochaetopterus sp. 1 & 2.1 & 71.2 & $\mathrm{SF}$ \\
\hline Blennidae indet. & 5.9 & 78.2 & CAR & Portunus cf. longispinosus & 2.1 & 73.3 & CAR \\
\hline
\end{tabular}


all BR stations (Stns 14, 34, 44, 54), stations of the Residential Zone (Stns 42,43 and 44) and Stns 12, 32 and 53. Carnivores and non-selective deposit-feeders were the dominant trophic types present at these stations. Non-selective deposit-feeders such as Dasybranchus spp. were also dominant species at TR stations (Stns
12, 32, 42 and 52), whereas carnivores and selective deposit-feeding amphinomids (Eurythoe sp. 1 and Linopherus sp. 1) dominated BR stations (Stns 14, 34, 44 and 54). Phyllochaetopterus spp. and Mesochaetopterus spp. (suspension-feeding chaetopterids) were also present (Fig. 8B).

Table 3. (continued)

\begin{tabular}{|c|c|c|c|c|c|c|c|}
\hline Taxon & $\begin{array}{c}\text { Total } \\
\text { iomass (\%) }\end{array}$ & $\begin{array}{l}\text { Cum. } \\
(\%)\end{array}$ & $\begin{array}{l}\text { Trophic } \\
\text { type }\end{array}$ & Taxon & $\begin{array}{c}\text { Total } \\
\text { biomass }(\%)\end{array}$ & $\underset{(\%)}{\text { Cum. }}$ & $\begin{array}{c}\text { Trophic } \\
\text { type }\end{array}$ \\
\hline \multicolumn{4}{|l|}{ Stn 41} & \multicolumn{4}{|l|}{$\operatorname{Stn} 51$} \\
\hline Spiochaetopterus sp. 1 & 21.8 & 21.8 & $\mathrm{SF}$ & Hippa cf. pacifica & 46.1 & 46.1 & CAR \\
\hline Phyllochaetopterus sp. 1 & 17.6 & 39.4 & $\mathrm{SF}$ & Rissoina ambigua & 7.6 & 53.7 & SDF \\
\hline Enteropneusta indet & 9.9 & 49.3 & NSDF & Rhinoclavis sinensis & 5.6 & 59.3 & SDF \\
\hline Patellidae indet. & 9.5 & 58.8 & HER & Codakia divergens & 5.3 & 64.6 & SDF \\
\hline Actinians & 5.2 & 64.0 & $\mathrm{SF}$ & Leptodius sp. 1 & 4.1 & 68.7 & HER \\
\hline Tellina rhomboides & 3.5 & 67.5 & SDF & Brachyura indet. & 4.1 & 72.8 & - \\
\hline Phyllochaetopterus sp. 2 & 3.4 & 70.9 & SF & Pyramidella sulcata & 3.8 & 76.6 & CAR \\
\hline Phylochaetopterus indet. & 3.4 & 74.2 & $\mathrm{SF}$ & Rissoina & 3.8 & 80.4 & SDF \\
\hline Calappa hepatica & 2.5 & 76.8 & CAR & Chaetopteridae indet. & 2.7 & 83.1 & SF \\
\hline Huenia sp. 1 & 2.5 & 79.3 & HER & Gobiidae indet. & 2.6 & 85.6 & CAR \\
\hline Otopleura mitralis & 2.4 & 81.7 & CAR & & & & \\
\hline Nerita morio & 2.4 & 84.1 & HER & Stn 52 & & & \\
\hline \multirow[t]{2}{*}{ Linopherus sp. 1} & 2.3 & 86.4 & $\mathrm{SDF}$ & Venus toreuma & 17.3 & 17.3 & $\mathrm{SF}$ \\
\hline & & & & Tellina rhomboides & 13.0 & 30.4 & $\mathrm{SDF}$ \\
\hline \multicolumn{4}{|l|}{$\operatorname{Stn} 42$} & Nassarius rehderi & 10.5 & 40.9 & CAR \\
\hline Tellina oahuana & 26.4 & 26.4 & $\mathrm{SDF}$ & Terebra affinis & 6.7 & 47.6 & CAR \\
\hline Tellina donaciformis & 11.7 & 38.1 & SDF & Nassarius graniferus & 5.3 & 52.8 & CAR \\
\hline Tellina crebrimaculata & 10.8 & 48.9 & SDF & Nassarius tabescens & 5.3 & 58.1 & CAR \\
\hline Tellina rhomboides & 7.9 & 56.8 & SDF & Albunea speciosa & 5.2 & 63.3 & CAR \\
\hline Arcopagia robusta & 7.2 & 64.0 & SDF & Terebra langfordi & 4.4 & 67.8 & CAR \\
\hline Conus eburneus & 5.7 & 69.7 & CAR & Cancilla filaris & 3.7 & 71.5 & CAR \\
\hline Aspidosiphon sp. 1 & 2.8 & 72.5 & SDF & Tellina donaciformis & 3.1 & 74.6 & $\mathrm{SDF}$ \\
\hline Portunus cf. longispinosus & 2.8 & 75.4 & CAR & Nassarius splendidulus & 2.6 & 77.2 & CAR \\
\hline Terebra affinis & 2.2 & 77.6 & CAR & Philyra sp. 1 & 2.4 & 79.6 & HER \\
\hline \multirow[t]{2}{*}{ Enteropneusta indet. } & 2.2 & 79.8 & NSDF & Atys cylindricus & 2.2 & 81.8 & CAR \\
\hline & & & & Nassarius indet. & 2.2 & 84.0 & CAR \\
\hline \multicolumn{2}{|l|}{ Stn 43} & & & Terebra indet. & 2.2 & 86.3 & CAR \\
\hline Tellina oahuana & 13.6 & 13.6 & $\mathrm{SDF}$ & Strombidae indet. & 2.2 & 88.5 & $\mathrm{SDF}$ \\
\hline Conus eburneus & 11.8 & 25.4 & CAR & & & & \\
\hline Conus pulicarius & 11.8 & 37.1 & CAR & Stn 53 & & & \\
\hline Tellina rhomboides & 7.2 & 44.3 & SDF & Corbula tahitensis & 18.7 & 18.7 & SDF \\
\hline Arcopagia robusta & 6.8 & 51.1 & SDF & Chlamys elegantissima & 15.7 & 34.4 & $\mathrm{SF}$ \\
\hline Terebra affinis & 6.0 & 57.1 & CAR & Venus toreuma & 15.0 & 49.4 & $\mathrm{SF}$ \\
\hline Corculum fragum & 5.1 & 62.3 & $\mathrm{SF}$ & Anodontia edentula & 6.7 & 56.0 & SDF \\
\hline Tellina crebrimaculata & 3.4 & 65.7 & $\mathrm{SDF}$ & Terebra longiscata & 4.2 & 60.3 & CAR \\
\hline Strombus gibberulus & 3.1 & 68.7 & $\mathrm{SDF}$ & Philyra sp. 1 & 3.0 & 63.2 & HER \\
\hline Aspidosiphon sp. 1 & 2.9 & 71.7 & SDF & Natica gualteriana & 2.6 & 65.8 & CAR \\
\hline Dasybranchus sp. 1 & 2.2 & 73.8 & NSDF & Nassarius coronatum & 2.0 & 67.8 & CAR \\
\hline \multirow[t]{2}{*}{ Rhinoclavis diadema } & 2.1 & 75.9 & SDF & & & & \\
\hline & & & & $\operatorname{Sin} 54$ & & & \\
\hline \multicolumn{2}{|l|}{$\operatorname{Stn} 44$} & & & Tellina oahuana & 15.4 & 15.4 & SDF \\
\hline Terebra affinis & 14.7 & 14.7 & SDF & Terebra affinis & 12.2 & 27.5 & CAR \\
\hline Tellina oahuana & 11.9 & 26.5 & SDF & Conus pulicarius & 11.2 & 38.7 & CAR \\
\hline Cerithium salebrosum & 10.2 & 36.7 & SDF & Tellina rhomboides & 10.3 & 49.0 & SDF \\
\hline Tellina rhomboides & 9.1 & 45.8 & $\mathrm{SDF}$ & Nassarius graniferus & 9.1 & 58.2 & CAR \\
\hline Conus striatus & 6.1 & 51.9 & CAR & Dasybranchus sp. 1 & 6.2 & 64.4 & NSDF \\
\hline Terebra maculata & 5.0 & 56.9 & CAR & Conus tessulatus & 5.6 & 70.0 & CAR \\
\hline Portunus cf. longispinosus & 4.8 & 61.7 & CAR & Actinians & 2.5 & 72.4 & $\mathrm{SF}$ \\
\hline Tellina crebrimaculata & 3.5 & 65.2 & SDF & Vexillum cadaverosum & 2.3 & 74.7 & CAR \\
\hline Cerithium nesioticum & 3.1 & 68.3 & SDF & & & & \\
\hline Rhinoclavis diadema & 2.3 & 70.6 & SDF & & & & \\
\hline
\end{tabular}




\section{Environmental effects}

All environmental variables were significantly correlated with grain size ( $\mathrm{Tm})$, except for chlorophyll content (Chl). Silt, total organic matter (OM) and phaeopigment (Phaeo) variables showed the most significant correlations (Table 4). The use of multiple regression analysis to show environmental effects was then possible as this method is best fitted for correlated factors (Karakassis \& Eleftheriou 1997). Using this analysis showed that the amount of chlorophyll present in the sediment was not a significant factor in explaining macrofaunal distributional patterns $(p=0.53)$ (Table 5), and was therefore not included in Fig. 7. Redox potential at $5 \mathrm{~cm}$ depth in sediments (Eh5) also had little effect on the community structure. The other environmental variables, grain size (TM and Silt), Phaeo and OM best explained the variance exhibited by the macrofauna data (Fig. 7). Silt and Phaeo were responsible for the gradient in communities from Group III to Group I. Stations of Group III showed high grain size and no silt or phaeopigment enrichment, whereas in the opposite direction of that gradient Group I homogeneity was related to highest loads in Silt and Phaeo, and OM to a lesser extent.

\section{DISCUSSION}

Shallow coastal ecosystems in the tropics depend on nutrients derived from terrigenous inputs (Chardy \& Clavier 1988, Alongi 1990). In Tahiti, coastal, and river runoff is responsible for transporting large amounts of terrestrially derived sediments into the lagoon. Lafforgue (1994) estimated that up to $61 \mathrm{t}$ of particulate matter may be transported by a small river into the lagoon of Tahiti during a cyclone lasting $4 \mathrm{~d}$. Using estimates of the basaltic content of lagoonal sediments, as an indication of terrestrially derived particles, it is clear that they can be transported to the barrier reef sites, even when a large channel is present. This is clearly shown in the Reference Zone (Zone 5). However such terrestrially derived particles mostly settled in the channel part, with minimum sedimentation on fringing reefs and inner flats of the barrier reef. The high levels of silt and associated high organic loads, as a result of

Fig. 7. Two-dimensional MDS ordination for macrofauna biomass with superimposed cluster groups (solid lines, 21 to $24 \%$ similarity; dashed lines, 34 to $40 \%$ similarity). Arrows show directions of increase for each significant environmental variable. Numbers following variable designation indicate the percentage of variance explained by each variable and defined with the multiple regression. Groups cited in the text are numbered from I to III (Tm, mean grain size; Eh5, redox potential at $5 \mathrm{~cm}$ depth in sediment; Phaeo, phaeopigment content; Silt percentage of silt and clay; $O M$, total organic matter load) 
land runoff were most evident in the populated zones (Zones 1, 2 and 3), while BR areas and sparsely populated zones (Zones 4 and 5) were not subjected to high organic matter, silt and basaltic loads. In the siltenriched zones, the maximum loads were recorded at $\mathrm{CH}$ and TR stations. An exception to this was found at Stn 53, where the high silt content was probably related to the presence of a Halophila seagrass bed which increased depositional rates (e.g. Curras et al. 1994, Everett 1994). Levels of phaeopigment were strongly correlated with silt content, but not with chlorophyll content, with maximum values being recorded in channels. This suggests that the silt and phaeopigments present in the sediments may have similar origins, probably terrestrial sources. The terrigenous inputs were identified by Harris (1998) by measurements of metals ( $\mathrm{Cr}, \mathrm{Ni}, \mathrm{Al}, \mathrm{Fe}, \mathrm{Mn}$ ) and polycyclic aromatic hydrocarbons. In summary the channel areas were highly impacted by terrestrially derived sediments, as shown by organic matter, silt and basaltic loads.

A schematic figure based on the trophic groups of the total macrofauna and polychaete communities (Fig. 9) illustrates the different feeding patterns of the
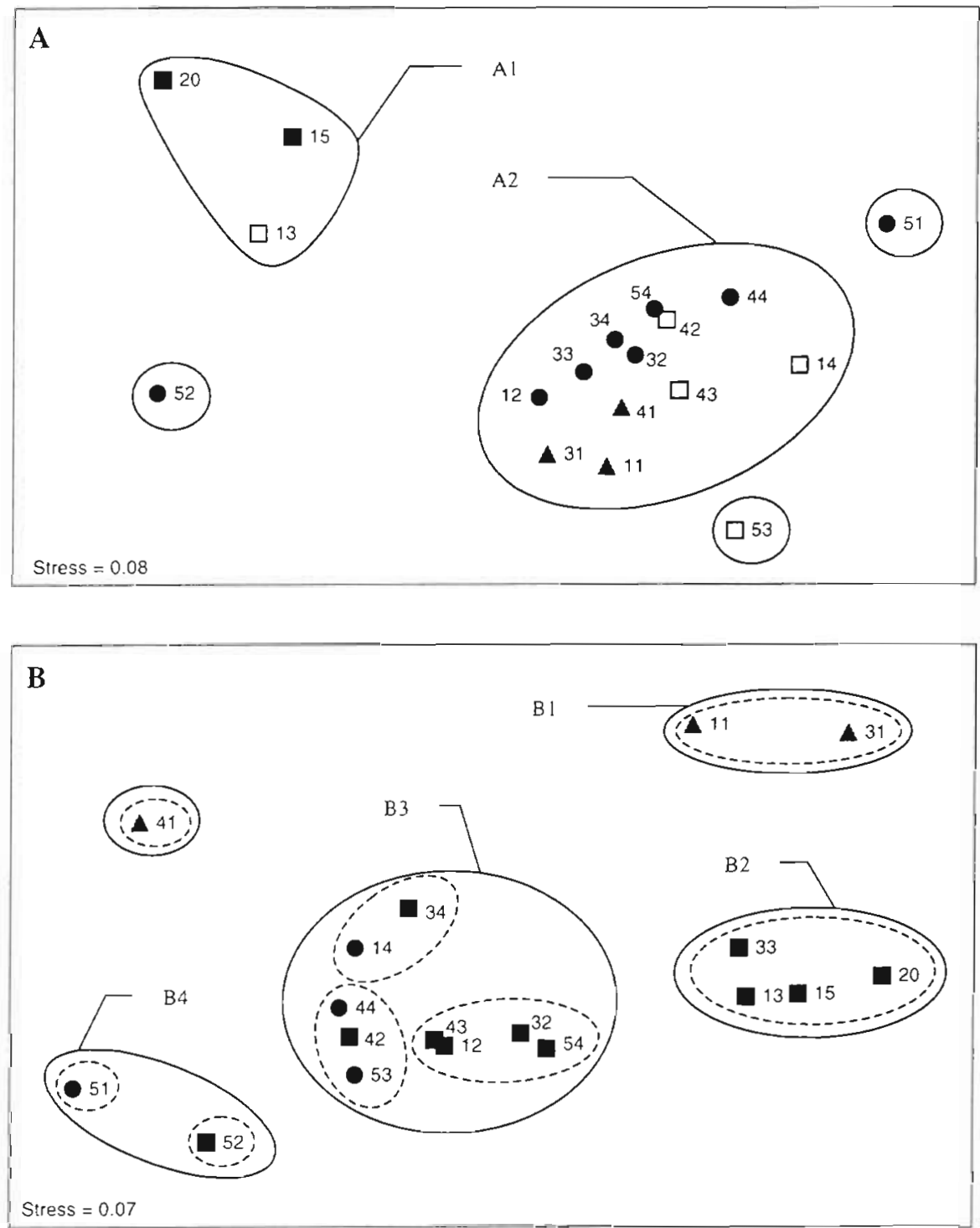

Fig. 8. Two-dimensional MDS ordination on biomass data for the 18 stations. (A) Ordination for trophic types of all macrofauna Solid lines show cluster groups with $85 \%$ similarity (Bray-Curtis index). Groups cited in the text are labelled A1 and A2. (B) Ordination for polychaete trophic types. Solid lines are for cluster groups with 35 to $50 \%$ similarity, dashed lines for groups with $65 \%$ similarity. Groups cited in the text are labelled from B1 to B4 (symbols for the dominant trophic type in the station are: $\mathbf{\square}$, nonselective deposit-feeders; $\square$, selective deposit-feeders; $\boldsymbol{\Delta}$, suspension feeders; $\bullet$, carnivores) 


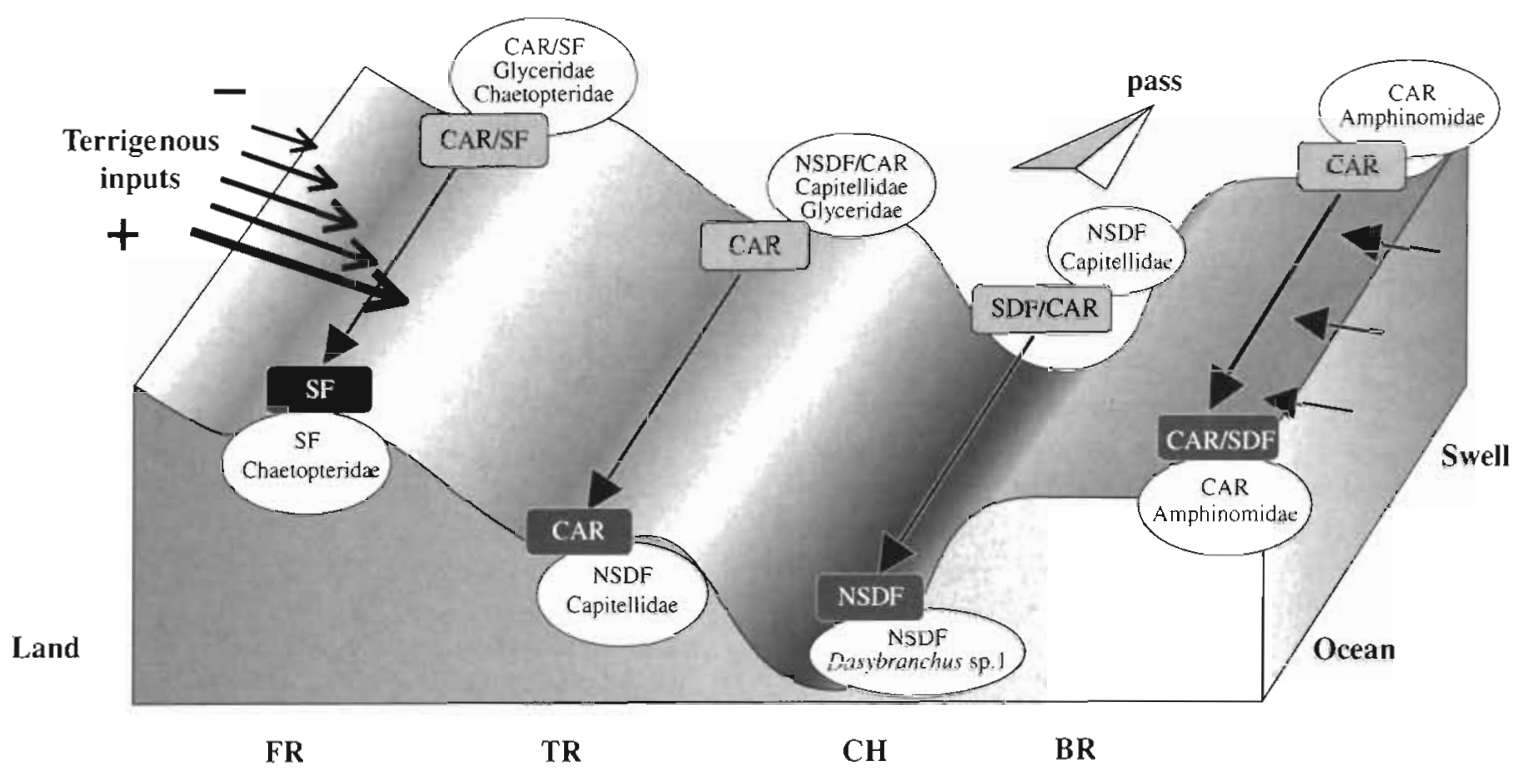

Fig. 9. Idealised functioning of a reef complex section from shore to barrier reef (FR, fringing reef; TR, fringing reef-channel transition; $\mathrm{CH}$, channel; $\mathrm{BR}$, barrier reef), for a high island subjected to increasing terrigenous inputs. On the landward side, terrigenous inputs increase from background to foreground and control the communities down to the channel. On the seaward side, swells protect the inner flats of the barrier reef from terrigenous influences. Within boxes are the dominant trophic groups for total macrofauna, encircled are those for polychaete taxa, with specification of dominant taxa (CAR, carnivores; SF, suspensionfeeders; SDF, selective deposit-feeders; NSDF, non-selective deposit-feeders). Black arrows represent the shift from nonimpacted ecosystem to impacted ecosystem with terrigenous elements

macrobenthos and how these relate to terrigenous inputs, across the lagoon from the fringing to the barrier reef. It is suggested that the type of sediment present as well as terrigenous inputs, and the type of reefal habitat all play major roles in determining the community structure. This is consistent with conclusions from many macrobenthic studies which show that community structure is largely dependent on sediment grain size (Alongi 1986, Riddle 1988, Agard et al. 1993, Long \& Poiner 1994, Karakassis \& Eleftheriou 1997, Harvey et al. 1998). Fig. 9 illustrates how inputs flow out over the FR part of the lagoon where low rates of sedimentation were observed. In FR areas, chaetopterid communities trap suspended sediments in the water col-

Table 4. Correlation between environmental variables ( $\mathrm{Tm}$, mean grain size; Eh 5 , redox potential at $5 \mathrm{~cm}$ depth in sediment; Phaeo, phaeopigments: $\mathrm{Chl}$, chlorophyll; Silt, silt and clay; OM, total organic matter). $p<0.05, \cdots p<0.01, \cdots p<0.001$

\begin{tabular}{|c|c|c|c|c|c|c|}
\hline & $\operatorname{Tm}$ & Eh5 & Depth & Phaeo & Chl & Silt \\
\hline Ehs & $0.71^{\cdots}$ & 1 & & & & \\
\hline Depth & $-0.70^{\cdots}$ & -0.43 & 1 & & & \\
\hline Phaeo & $-0.71^{\cdots}$ & $-0.52^{\circ}$ & $0.59^{\circ}$ & 1 & & \\
\hline Chl & -0.24 & -0.40 & -0.10 & 0.39 & 1 & \\
\hline Silt & $-0.75 \cdots$ & $-0.53^{\circ}$ & $0.54^{\circ}$ & $0.93 \cdots$ & 0.24 & 1 \\
\hline OM & $-0.58^{\circ}$ & -0.36 & $0.63 *$ & $0.77 \cdots$ & 0.05 & $0.80^{\cdots}$ \\
\hline
\end{tabular}

umn and their high density of tubes stabilises the sediments (Bailey-Brock 1979). Such behaviour by suspension-feeders (chaetopterids) plays an important facilitation role for associated communities in the $\mathrm{FR}$ subsystem (Bailey-Brock 1979, Gallagher et al. 1983). Chaetopterids tended to dominate FR communities in Tahiti lagoon, which were subjected to high levels of terrigenous inputs. This is consistent with studies by Heip (1995) that increasing rates of suspended matter in the water column increase the abundance of suspension-feeders. Pastorok \& Bilyard (1985) showed that moderate sewage inputs may mimic nutrient enrichment and promote rapid growth of benthic organisms and domination by benthic suspension-feeders. Towards the $\mathrm{CH}$ part of the lagoon, as sedimentation rates increased, macrobenthic communities shifted from a carnivore-dominant mode (TR) to a non-selective deposit-feeding mode (CH). Driscoll (1975) noted that deposit-feeding benthos was favoured by finegrained sediments characterised by high organic content. For polychaete communities (Fig. 9), non-selective deposit feeding was the dominant mode in TR and $\mathrm{CH}$ parts, with capitellids and particularly Dasybranchus sp. 1 contributing most to the biomass of the communities in the $\mathrm{CH}$ zone. At this point, a convergence of waters from the land with oceanic waters transversing the inner flat of the barrier reef occurs, 
enhancing sedimentation rates in the channel area. The resulting current is then directed toward the passes (pers. obs.). Wolanski et al. (1993) studied the hydrodynamics of the lagoon of Moorea, which is a high island close and similar to Tahiti, and found a similar pattern. On the ocean side, the BR system, isolated from terrigenous influence by swell effect, exhibited structured macrobenthic communities dominated by carnivores, suggesting that carnivores are the dominant group where terrigenous inputs are minimal. However, in non-impacted zones polychaetes were more responsive to the reefal structure, with non-selective deposit-feeders being best represented in $\mathrm{CH}$ locations, which act as settlement pools for particles.

The increased particulate enrichment from the nonurbanised zones to the harbour area did not cause a linear reaction from the macrobenthos. If the $S A B$ curves (Fig. 6) are considered, the response of communities represented a bell-shaped line, with maximum $\mathrm{SAB}$ values corresponding to intermediate levels of enrichment. The response of the Tahitian ecosystem to increasing terrestrial inputs corresponds to the intermediate disturbance hypothesis proposed by Connell (1978), in which high diversity is maintained by disturbance operating at intermediate levels. Our results from Tahiti can be compared to those of several authors who have applied this hypothesis to explain the functioning of tropical ecosystems (e.g. Warwick \& Ruswahyuni 1987, Grigg \& Dollar 1990, Dollar \& Tribble 1993). A complementary study on microbenthos in Tahiti lagoon (Torréton et al. 1997) supported the hypothesis that these communities are food limited. The increasing SAB values found in this study support this hypothesis (Fig. 6). Some authors argue that biogenic disturbance (Riddle et al. 1990) or low metabolic rates (Grigg et al. 1984) play a major role in community limitation compared to nutrient depletion. However, food limitation in tropical systems was suggested in several cases (Alongi \& Christoffersen 1992, Edgar 1993, Long \& Poiner 1994). In the Tahitian lagoon, terrigenous inputs may minimise this limitation.

The mean organic content of sediments of $4.3 \%$ $\left(60.72 \pm 2.43 \mu \mathrm{g} \mathrm{AFDW} \mathrm{cm}^{-2}\right)$ for a major group of 13 stations (Fig. 4) was close to the value of $53.02 \mu \mathrm{g}$ AFDW $\mathrm{cm}^{-2}$ recorded from the white sand sediments of the New Caledonian lagoon by Chardy \& Clavier (1988) and slightly higher than recorded from some French Polynesian atoll lagoons $(2.47$ to $3.80 \%$ from Hily \& Frouin 1998) or from isolated carbonate reefs (0.1 to $0.7 \%$ of organic carbon in Hansen et al. 1987 , Riddle 1988, Alongi 1989). The high total organic content recorded at Stn 53 in Tahiti was directly related to the presence of a seagrass bed (see Everett 1994). Subsurface roots and leaves incorporated into the sediments increased the organic matter content of the sedi-
Table 5. Multiple regression analysis between environmental factors and MDS scores. Adjusted coefficient of determination accounts for the part of variance explained by the variable. $\mathrm{R}^{2}$ was tested with ANOVA $(\mathrm{df}=2,15)(\mathrm{Tm}$, mean grain size Eh5, redox potential at $5 \mathrm{~cm}$ depth in sediment; Phaeo, phaeopigment content; $\mathrm{Chl}$, chlorophyll content; Silt, percentage of silt and clay; OM, total organic matter load)

\begin{tabular}{|c|c|c|c|c|c|}
\hline \multirow[t]{2}{*}{ Variable } & \multicolumn{2}{|c|}{ Direction cosines } & \multirow[t]{2}{*}{ Adjusted $\mathrm{R}^{2}$} & \multirow[t]{2}{*}{$F$} & \multirow[t]{2}{*}{$p$-values } \\
\hline & $X$ & y & & & \\
\hline $\operatorname{Tm}$ & 0.839 & 0.543 & 0.658 & 17.374 & 0.000 \\
\hline Eh5 & 0.796 & 0.605 & 0.383 & 6.287 & 0.010 \\
\hline Depth & -0.925 & -0.379 & 0.472 & 8.580 & 0.003 \\
\hline Phaeo & -0.581 & -0.814 & 0.751 & 26.694 & 0.000 \\
\hline $\mathrm{Chla}$ & -0.979 & -0.202 & 0.040 & 0.6713 & 0.526 \\
\hline Silt & -0.508 & -0.861 & 0.782 & 31.457 & 0.000 \\
\hline $\mathrm{OM}$ & -0.629 & -0.778 & 0.547 & 11.253 & 0.001 \\
\hline
\end{tabular}

ment. It is suggested that Stn 52 was subjected to enrichment by plant material and detritus imported from Stn 53 during periodic heavy swell or wind events. However, terrestrially derived organic inputs cannot be excluded as Zone 5 had a high percentage of basaltic sediments. High levels of organic matter present at Stns 13,15 and 20 appear to be related to anthropogenic organic inputs from sewage and polluted rivers. Also at Stns 15 and 20, sediments contained 60 to $70 \%$ of silt. Generally, such conditions result in low oxygen levels leading to defaunation (Nilsson \& Rosenberg 1994), but in the Tahitian ecosystem diverse communities occurred in these highly enriched sediments. Actually redox measurements showed that muddy sediments were oxygenated (redox $>200 \mathrm{mV}$; Fenchel 1969) down to depths of $20 \mathrm{~cm}$, the length of the cores. It is suggested that this is because of bioturbation of sediments and irrigation of burrows by Callianassa spp. and Alpheus spp. Burrow densities of these decapods were up to 436 \pm 21 burrow openings per square metre ( $\operatorname{Stn} 20 ; n=12$ ), and these species are known to have complex burrows, which may be 1 to $2 \mathrm{~m}$ in depth (Vaugelas de 1985, Nickell \& Atkinson 1995). Such complex burrows and the high mobility of these organisms were probably responsible for them being poorly represented in benthic samples (Ansell et al. 1972, Chardy et al. 1988, Frouin et al. 1998). Water flux in burrows generated by ventilation associated with interstitial water circulation due to sediment-reworking greatly contributes to the oxygenation of sediments (Forster \& Graf 1992, Ziebis et al. 1996) and favours the persistence or the settlement of other macrobenthic populations. Moreover, their activity is also important in incorporating organic matter into deeper layers of the sediment and recycling in relation to the bacterial loop (Driscoll 1975, Anderson \& Meadows 1978, Daumas 1990, Ebenhöh et al. 1995). In the highly impacted Harbour Zone, it is suggested that decapod activity is the key element in maintaining the di- 
verse macrofaunal community. It appears that no equivalent ecological process has been recorded from temperate systems.

It is strongly recommended that additional studies are carried out to confirm this important role, and the possible risks if decapod populations are not maintained. Reductions of the decapod population, or even loss of them, could lead to anoxic conditions developing and under such conditions, loss of the macrobenthic communities. This could have major impacts on the marine ecosystem of this region.

In conclusion, this study has shown that the lagoon of Tahiti is ideally suited for studying disturbance, with enhanced effects on a small spatial scale (the lagoon never exceeds $2 \mathrm{~km}$ in width). Inputs from terrestrial sources into the lagoon were composed of fine terrigenous elements (silt and clay) and organic matter, and the amount of these inputs was related to coastal population densities. Lagoonal hydrodynamic patterns also played an important role in the functioning of the ecosystem. Particulate organic and inorganic enrichment leads to a simplified trophic structure dominated by non-selective deposit-feeders, Dasybranchus sp. 1. In areas of high sedimentation bioturbation by decapods ensures that the sediments remain aerated and that diverse benthic communities are maintained.

Acknowledgements. I would like to thank J. Orempüller, N. Maihota, J. Paoaafaite and J. Teuri for their assistance in field and laboratory. I am also grateful to I. Karakassis tor useful comments. Pat Hutchings corrected the initial drafts of this manuscript. This research was funded by ORSTOM (now IRD), the French Ministry for Education and Research, the French University of the Pacific, and the Research and Environment Delegations of French Polynesia.

\section{LITERATURE CITED}

Agard JBR, Gobin J, Warwick RM (1993) Analysis on marine macrobenthic community structure in relation to pollution, natural oil seepage and seasonal disturbance in a tropical environment (Trinidad, West Indies). Mar Ecol Prog Ser 92:233-243

Alongi DM (1986) Population structure and trophic composition of the free-living nematodes inhabiting carbonate sands of Davies Reef, Great Barrier Reef, Australia. Aust J Mar Freshw Res 37:609-619

Alongi DM (1989) The role of soft-bottom benthic communities in tropical mangroves and coral reef ecosystems. CRC Crit Rev Aquat Sci 1:243-280

Alongi DM (1990) The ecology of tropical soft-bottom benthic ecosystems. Oceanogr Mar Biol Annu Rev 28:381-496

Alongi DM, Christoffersen P (1992) Benthic infauna and organism-sediment relations in a shallow, tropical coastal area: influence of outwelled mangrove detritus and physical disturbance. Mar Ecol Prog Ser 81:229-245

Anderson JG. Meadows PS (1978) Microenvironments in marine sediments. Proc R Soc Edinb Sect B Biol Sci $76: 1-16$

Ansell AD, Sivadas P, Narayanan B, Sankaranarayanan VN,
Trevallion A (1972) The ecology of two sandy beaches in South West India. I. Seasonal changes in physical and chemical factors, and in the macrofauna. Mar Biol 17:38-62

Bailey-Brock JH (1979) Sediment trapping by chaetopterid polychaetes on a Hawailan fringing reef. J Mar Res 37:643-655

Chardy P, Clavier J (1988) Biomass and trophic structure of the macrobenthos in the south-west lagoon of New Caledonia. Mar Biol 99:195-202

Chardy P, Chevillon C, Clavier J (1988) Major benthic communities of the south-west lagoon of New-Caledonia Coral Reefs 7:69-75

Clarke KR, Ainsworth M (1993) A method of linking multivariate community structure to environmental variables. Mar Ecol Prog Ser 92:205-219

Clarke KR, Green RH (1988) Statistical design and analysis for a 'biological effect' study. Mar Ecol Prog Ser 46: $213-226$

Connell JH (1978) Diversity in tropical rain forests and coral reefs. Science 199:1302-1310

Curras A, Sanchez-Mata A, Mora J (1994) Estudio comparativo de la macrofauna bentonica de un fondo de Zostera marina y un fondo arenoso libre de cubierta vegetal. Cah Biol Mar 35:91-112

Daumas R (1990) Contribution of the water-sediment interface to the transformation of biogenic substances: application to nitrogen compounds. Hydrobiologia 207:15-29

Dollar SJ, Tribble GW (1993) Recurrent storm disturbance and recovery - a long-term study of coral communities in Hawaii. Coral Reefs 12:223-233

Driscoll EG (1975) Sediment-animal-water interaction, Buzzards Bay, Massachusetts. J Mar Res 33:275-302

Ebenhöh W, Kohlmeier C, Radford PJ (1995) The benthic biological submodel in the European Regional Seas Ecosystem Model. Neth J Sea Res 33:423-452

Edgar GJ (1993) Estimates of the carrying capacity of benthic habitats using a metabolic-rate based index. Oecologia 95:115-121

Ellis JI, Schneider DC (1997) Evaluation of a gradient sampling design for environmental impact assessment. Environ Monit Assess 48:157-172

Engle VD, Summers JK, Gaston GR (1994) A benthic index of environmental condition of Gulf of Mexico estuaries. Estuaries $17.372-384$

Everett RA (1994) Macroalgat in marine soft-sediment communities: effects on benthic faunal assemblages. J Exp Mar Biol Ecol 175:253-274

Fauchald K, Jumars P (1979) The diet of worms: a study of polychaete feeding guilds. Oceanogr Mar Biol Annu Rev 17:193-284

Fenchel TM (1969) The ecology of marine microbenthos. IV. Structure and function of the benthic ecosystem, its chemical and physical factors and the microfauna communities with special reference to the ciliated protozoa. Ophelia 6: $1-182$

Ferraro SP, Cole FA (1992) Taxonomic level sufficient for assessing a moderate impact on macrobenthic communities in Puget Sound, Washington, USA. Can J Fish Aquat Sci 49:1184-1188

Field JG, Clarke KR. Warwick RM (1982) A practical strategy for analysing multispecies distribution patterns. Mar Ecol Prog Ser 8:37-52

Folk RL, Ward NC (1957) Brazos River Bar: a study of the significance of grain size parameters. J Sediment Petrol 27: 3-26

Forbes TL, Forbes VE, Depledge MH (1994) Individual physiological responses to environmental hypoxia and organic 
enrichment: implications for early soft-bottom community succession. J Mar Res 52:1081-1100

Forster S. Graf G (1992) Continuously measured changes in redox potential influenced by oxygen penetrating from burrows of Callianassa subterranea. Hydrobiologia 235/236: $527-532$

Frouin P (1996) Structure et fonctionnement des écosystèmes benthiques des lagons soumis aux perturbations anthropiques: le lagon de Tahiti (Polynésie française). PhD thesis, French University of the Pacific, Papeete

Frouin $P$, Hutchings $P$ (in press) Macrobenthic communities in a tropical lagoon (Tahiti, French Polynesia, Central Pacific Ocean). Coral Reefs

Frouin P, Hily C, Hutchings P (1998) Ecology of spionid polychaetes in the swash zone of exposed beaches in Tahiti (French Polynesia). C R Acad Sci Ser III Life Sci 321:47-54

Gallagher ED, Jumars PA, Trueblood DD (1983) Facilitation of soft-bottom benthic succession by tube-builders. Ecology $64: 1200-1216$

Grigg RW, Dollar SJ (1990) Natural and anthropogenic disturbance on coral reefs. In: Dubinsky $Z$ (ed) Ecosystems of the world: coral reefs, Vol 25. Elsevier Science. Amsterdam, p 439-452

Grigg RW, Polovina JJ, Atkinson MJ (1984) Model of a coral reef ecosystem. III. Resource limitation, community regulation, fisheries yield and resource management. Coral Reefs 3:23-27

Hansen JA, Alongi DM, Moriarty DJW, Pollard PC (1987) The dynamics of benthic microbial communities at Davies Reef, central Great Barrier Reef. Coral Reefs 6:63-70

Harris P (1998) Modification des caractéristiques chimiques du lagon de Papeete liées à l'activité humaine: intérêt des traceurs sédimentaires géochimiques et biogéochimiques dans la reconstitution de l'évolution de l'environnement au cours des 150 dernières années. PhD thesis, French University of the Pacific, Papeete

Harvey M, Gauthier D. Munro J (1998) Temporal changes in the composition and abundance of the macro-benthic invertebrate communities at dredged material disposal sites in the Anse a Beaufils, Baie des Chaleurs, Eastern Canada. Mar Pollut Bull 36:41-55

Hatcher BG, Johannes RE, Robertson AI (1989) Review of research relevant to the conservation of shallow tropical marine ecosystems. Oceanogr Mar Biol Annu Rev 27:337-414

Heip C (1995) Eutrophication and zoobenthos dynamics. Ophelia 41:113-136

Hily C (1985) Écologie de la macrofaune benthique dans les sédiments du port de Brest pollués par la matière organique. Oceanis 11:263-276

Hily C, Frouin P (1998) Short term bioturbation activity in the lagoonal sediments of Tikehau atoll (Tuamotu Archipelago, French Polynesia). Int Rev Hydrobiol 83:335-347

Holm-Hansen O, Lørenzen CJ, Holmes RW, Strickland JDH (1965) Fluorometric determination of chlorophyll. J Cons Int Explor Mer 30:3-15

Hutchings P, Payri C, Gabrié C (1994) The current status of coral reef managment in French Polynesia. Mar Pollut Bull 29:26-33

Karakassis I, Eleftheriou A (1997) The continental shelf of Crete: structure of macrobenthic communities. Mar Ecol Prog Ser 160:185-196

Keough MJ, Quinn GP (1991) Causality and the choice of measurements for detecting human impacts in marine environments. Aust J Mar Freshw Res 42:539-554

Krumbein WC (1936) Application of logarithmic moments to size frequency distribution of sediments. J Sediment Petrol 6:35-47
Kruskal JB, Wish M (1978) Multidimensional scaling. Sage University Paper series on Quantitative Applications in the Social Sciences, 07-011. Sage Publications, Newbury Park, CA

Lafforgue A (1984) Hydrologie de I'île de Tahiti (aide-mémoire succinct\}. Archives d'hydrologie Centre ORSTOM de Tahiti 84-13:1-13

Lafforgue A (1994) Étude hydrologique pour l'aménagement de la rivière Nymphea. Rapport de campagne et éléments de calcul pour les ouvrages d'assainissement des zones urbanisées du secteur Faaa-Punnauia. Hydro Consult International-GIE ORSTOM EDF, Papeete

Long BG, Poiner IR (1994) Infaunal benthic community structure and function in the Gulf of Carpentaria, Northern Australia. Aust J Mar Freshw Res 45:293-316

Lorenzen CJ (1967) Determination of chlorophyll and phaeopigments: spectrophotometric equations. Limnol Oceanogr 12:343-346

Nickell LA, Atkinson RJA (1995) Functional morphology of burrows and trophic modes of three thalassinidean shrimp species, and a new approach to the classification of thalassinidean burrow morphology. Mar Ecol Prog Ser 128 $181-197$

Nilsson HC, Rosenberg R (1994) Hypoxic response of two marine benthic communities. Mar Ecol Prog Ser 115 209-217

Pastorok RA, Bilyard GR (1985) Effects of sewage pollution on coral reefs communities. Mar Ecol Prog Ser 21:175-189

Pearson TH, Rosenberg R (1978) Macrobenthic succession in relation to organic enrichment and pollution of the marine environment. Oceanogr Mar Biol Annu Rev 16:229-311

Plantecuny MR, Salen-Picard C, Grenz C, Plante R, Alliot E, Barranguet $C$ (1993) Experimental field study of the effects of crude oil, drill cuttings and natural biodeposits on microphytozoobenthic and macrozoobenthic communities in a Mediterranean Area. Mar Biol 117:355-366

Riddle MJ (1988) Patterns in the distribution of macrofaunal communities in coral reef sediment on the central Great Barrier Reef. Mar Ecol Prog Ser 47:281-292

Riddle MJ, Alongi DM, Dayton PK, Hansen JA, Klumpp DW (1990) Detrital pathways in a coral reef lagoon. Mar Biol 104:109-118

Torréton JP, Fouquet O, Frouin P (1997) Bacteriobenthos biomass and productivity in relation to organic matter in the lagoon of Tahiti, Vol 2. In: Lessios HA, MacIntyre IG (eds) Proc 8th Int Coral Reef Symp. Smithsonian Tropical Research Institute, Balboa, Panama, p 1857-1862

Vaugelas de J (1985) On the presence of the mud-shrimp Callichirus armatus in the sediments of Mataiva lagoon. Vol 6. In: Gabrié et al. (eds) Proc 5th Int Coral Reef Cong Antenne Museum-EPHE, Moorea, French Polynesia, p $314-317$

Warwick RM, Ruswahyuni (1987) Comparative study of the structure of some tropical and temperate marine soft-bottom macrobenthic communities. Mar Biol 95:641-649

Wolanski E, Delesalle B, Dufour V, Aubanel (1993) Modeling the fate of pollutants in the Tiahura lagoon, Moorea, French Polynesia. In: Proc 11th Aust Conf Coastal Ocean Engineering. Institution of Engineers, Townsville, p 583-587

Ziebis W, Forster S, Huettel M, Jargensen BB (1996) Complex burrows of the mud shrimp Callianassa truncata and their geochemical impact in the sea bed. Nature 382:619-622

Zmarzly DL, Stebbins TD, Pasko D, Duggan RM, Barwick KL (1994) Spatial patterns and temporal succession in softbottom macroinvertebrate assemblages surrounding an ocean outfall on the southern San Diego Shelf: relation to anthropogenic and natural events. Mar Biol 118:293-307 